\title{
Mesozooplankton composition and spatial distribution, Nuevo Gulf, Patagonia, Argentina
}

\author{
María C. Menéndez ${ }^{1 *}$, Florencia Biancalana ${ }^{1}$, Anabela A. Berasategui ${ }^{1}$, Melisa D. Fernández Severini ${ }^{1}$, \\ Mónica S. Hoffmeyer ${ }^{1,2}$ and José L. Esteves ${ }^{3}$ \\ 1 Instituto Argentino de Oceanografía, Centro Científico y Tecnológico Bahía Blanca, CONICET. Camino La Carrindanga km 7, B8000FWB. Bahía \\ Blanca, Buenos Aires, Argentina. \\ 2 Universidad Tecnológica Nacional, Facultad Regional Bahía Blanca. 11 de Abril 461, B8000LMI. Bahía Blanca, Buenos Aires, Argentina. \\ 3 Centro Nacional Patagónico, CONICET. Boulevard Brown 3500, U9120ACV. Puerto Madryn, Chubut, Argentina. \\ * Corresponding author. E-mail: menendez@criba.edu.ar
}

\begin{abstract}
The composition and spatial distribution of mesozooplankton of Nuevo Gulf, Argentina, were analyzed from surface samples taken on July, 1997. A total of 32 taxa were recorded. The highest abundances were found close to Nueva Bay, which is located nearby a growing urban population, whereas the lowest values were detected in the center of the gulf. Holoplankton dominated at all stations and evidenced a homogeneous spatial distribution. Meroplankton showed a more heterogeneous pattern. Ctenocalanus vanus was the most abundant taxon followed by Paracalanus parvus. Gastropoda veligers dominated the meroplanktonic fraction. Our results showed that the spatial distribution of the mesozooplankton seemed to be mainly influenced by the dominant hydrological circulation pattern of the region. This research establishes the first scientific basis for further studies in zooplankton communities of this important gulf, closely related to a natural protected worldwide known area declared a world heritage site by UNESCO.
\end{abstract}

\section{INTRODUCTION}

Nuevo Gulf is located on the Patagonian coast of

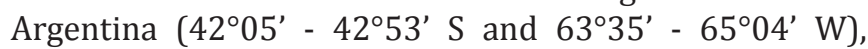
forming the southern and southwestern limits of Valdés Peninsula, a protected area declared a Wildlife Reserve by the United Nations Environment Program and World Conservation Monitoring Centre (UNEP-WCMC) on behalf of UNESCO (United Nations Educational, Scientific and Cultural Organization). Nuevo Gulf is well known as the site to which Eubalaena australis Desmoulins, 1822, the southern right whale, annually returns from the open sea for breeding purposes (Payne 1995). Nowadays, there is an increasing interest in determining whether right whales are feeding in their breeding grounds (Hoffmeyer et al. 2010). However, there are no studies concerning composition and abundance of zooplankton in Valdés Península nursery ground.

Nuevo Gulf has been the object of numerous physical and chemical oceanographic studies. The circulation of water masses has been studied mainly through numerical simulations (Barros and Krepper 1977; Rivas 1989; Mazio et al. 2004; Tonini et al. 2006) and, to a lesser extent, through direct measurements of currents (Krepper and Rivas 1979; Rivas 1983). A study on the thermal and saline structure of the gulf has been also carried out by Rivas and Beier (1990). Additionally, Esteves et al. (1996) performed studies on nutrients and phytoplankton composition in Nueva Bay, a small urban bay located on the west coast of the gulf, during different times of the year. However, there is no published information on the composition and spatial distribution of zooplankton communities in Nuevo Gulf, only some unpublished technical reports restricted to Nueva Bay area. The purposes of this work were to describe the surface mesozooplankton community of the
Nuevo Gulf during July 1997 as well as to analyze its spatial distribution pattern. Although this research focused on samples collected during a short lapse, the obtained results provide new knowledge which will contribute to establish a better baseline understanding for this important area closely related to a World Heritage site.

\section{Materials ANd MethodS \\ Study site}

Nuevo Gulf is a semi-enclosed basin of approximately $70 \mathrm{~km}$ long and $60 \mathrm{~km}$ wide. It covers a surface area of $2400 \mathrm{~km}^{2}$ and contains a volume of about $250 \mathrm{~km}^{3}$. More than one third of the gulf is deeper than $120 \mathrm{~m}$ whereas the maximum depth reaches $180 \mathrm{~m}$ in the central area. It is connected to the Atlantic Ocean through a shallow sill of an average depth of $44 \mathrm{~m}$ and a length of $16 \mathrm{~km}$ (Rivas and Ripa 1989). Tide is semidiurnal with variable amplitude ranging from $3.84 \mathrm{~m}$ for neap tides to $5.55 \mathrm{~m}$ for spring tides (Mazio et al. 2004). Nuevo Gulf displays a fully mixed water column in winter and stratified conditions in summer during which temperature is higher inside the gulf than in the surrounding shelf. Salinity is also higher inside the gulf all year long with slight vertical and horizontal variations. Human activities are principally concentrated in Puerto Madryn city and Puerto Pirámides town. Puerto Madryn city, which is located on the western coast of Nueva Bay, has the highest population density. Therefore, Nueva Bay receives all the effluents resulting from the urban, industrial (including fishing companies and an aluminium plant) and port activities carried out in Puerto Madryn (Esteves et al. 1996).

\section{Data collection}

Sampling was carried out from July 16 to $17,1997$. 
Mesozooplankton samples were collected at ten stations located in Nuevo Gulf during an oceanographic cruise on board "Puerto Deseado" vessel (Figure 1). At each station, an oblique tow was performed at the upper layer (0-5 m) using an open conical net (with a Kahlsico ${ }^{\circledR}$ flowmeter) with a $0.50 \mathrm{~m}$ mouth diameter and a $200 \mu \mathrm{m}$ mesh. Tow duration was between 5 and $10 \mathrm{~min}$ at approximately 2 knots. Samples were immediately preserved in $4 \%$ buffered formalin.

Surface salinity data were registered at each station using an YSY multi-parameter sonde. Surface temperature could not be registered due to a failure in the sensor of this instrument. It was therefore derived from an AVHRR PATHFINDER SST V5 image of the sampling date (http:// poet.jpl.nasa.gov/). Surface seawater samples $(0-1 \mathrm{~m})$ were collected with a Van Dorn bottle to determine the concentration of chlorophyll-a, phaeopigments, and particulate organic carbon (POC). Chlorophyll-a and phaeopigments were determined by fluorometric methods (Strickland and Parsons 1972) and POC by spectrophotometric technique (Strickland and Parsons 1972).

Zooplankton samples were firstly inspected under a Wild M5 stereoscopic microscope and all organisms were identified to the lowest possible taxonomic level using appropriate identification keys and descriptions. All the taxa present in each sample were counted. Abundance was calculated as the number of individuals per 100 cubic meter of water filtered through the net (ind. $100 \mathrm{~m}^{-3}$ ). The specimens of all taxa referred in this study were deposited in the zooplankton collection of the Instituto Argentino de Oceanografía, Bahía Blanca, Argentina.

\section{Data analysis}

Multivariate statistical analyses were performed using PRIMER-E ${ }^{\circledR}$ software package (Clarke and Warwick 1994). Non-metric multidimensional scaling (MDS) (Kruskal and Wish 1978) was applied to order stations and taxa in a two-dimensional plot. Square-root transformed data and the quantitative Bray-Curtis index were used (Clarke and Warwick 1994). Hierarchical agglomerative clustering under the same conditions and an average linkage were also used to determine the groups to be superimposed on the MDS plot when their stress values were $<0.2$ and $>0.1$. According to Clarke and Warwick (1994), when the stress value is lower than 0.1 , an MDS ordination is a more useful representation than a cluster analysis. For stress values between 0.1 and 0.2 , both techniques should be used as complements (Clarke and Warwick 1994). The clustering technique was also used to classify the stations according to salinity, chlorophyll-a, phaeopigments and POC.

\section{RESULTS AND DISCUSSION}

\section{Hydrological features of the study area}

Surface salinity showed low variability and ranged between 33.72 and 33.79 (Figure 2). The northern stations $(3,4,6$ and 10$)$ showed slightly higher values than southern stations (1, 2, 5, 7, 8, and 9) (Figure 2). Surface temperature values derived from AVHRR image ranged between 10.28 and $11.78^{\circ} \mathrm{C}$. It was observed that most of the gulf showed values higher than $11{ }^{\circ} \mathrm{C}$ and that outer waters were slightly colder than inner waters. Chlorophyll-a ranged between 0.06 and $0.68 \mathrm{mg} \mathrm{m}^{-3}$ and their spatial pattern showed maximum values at stations 4,7 , and 10 (Figure 2). These highest values were found at coastal stations, some of which (particularly those near Puerto Madryn and Puerto Pirámides) receive a high nutrient input from the coast due to anthropogenic activities, enabling the phytoplankton growing. Phaeopigments, indicative of a partial degradation of the chlorophyll-a as a result of zooplankton grazing, were only registered at stations 1 and 5, coinciding with the lowest chlorophyll-a values (Figure 2). POC values were similar at all stations and varied from 498 to $638 \mathrm{mg} \mathrm{m}^{-3}$, the exception being station 4 which revealed the lowest value (267 $\mathrm{mg} \mathrm{m}^{-3}$ ) (Figure 2).

\section{Mesozooplankton composition and abundance}

The mesozooplankton community was represented by 32 taxa (Table 1). Stations 2, 3 and 4, located near Puerto Madryn city, evidenced the highest number of taxa whereas station 9 (center of the gulf) showed the lowest number (Figure 3). The holoplankton fraction represented $59.4 \%$ of the total taxa observed whereas the remaining percentage corresponded to meroplankton (37.5\%) and adventitious plankton (3.1\%). Stations 1, 2, 3 and 4 showed the highest number of holoplanktonic taxa whereas stations 3, 4 and 10 revealed the highest number of meroplanktonic taxa (Figure 4). Copepoda was the most important group in the holoplanktonic fraction. However, Cladocera, Mysidacea, Amphipoda and Euphausiacea were also observed (Table 1). On the other hand, the meroplankton fraction included bryozoan ciphonautes, cirriped nauplii, decapod zoeae and megalopas, gastropod veligers, benthic polychaete nectochaets and fish eggs (Table 1). Tisbe varians Scott, 1914 was the only adventitious taxon found. The highest percentages of occurrence corresponded to Ctenocalanus vanus Giesbrecht, 1888, Paracalanus parvus Claus, 1863, Calanus australis Brodskii, 1959, Oithona similis Claus, 1863, Oithona nana Giesbrecht, 1892, Euterpina acutifrons Dana, 1852 and Oikopleura dioica Fol, 1872 larvae as well as to Podon intermedius Lilljeborg, 1901 (Table 1). Among the meroplankton taxa, veligers of Gastropoda and ciphonautes of Bryozoa showed the highest percentages (Table 1).

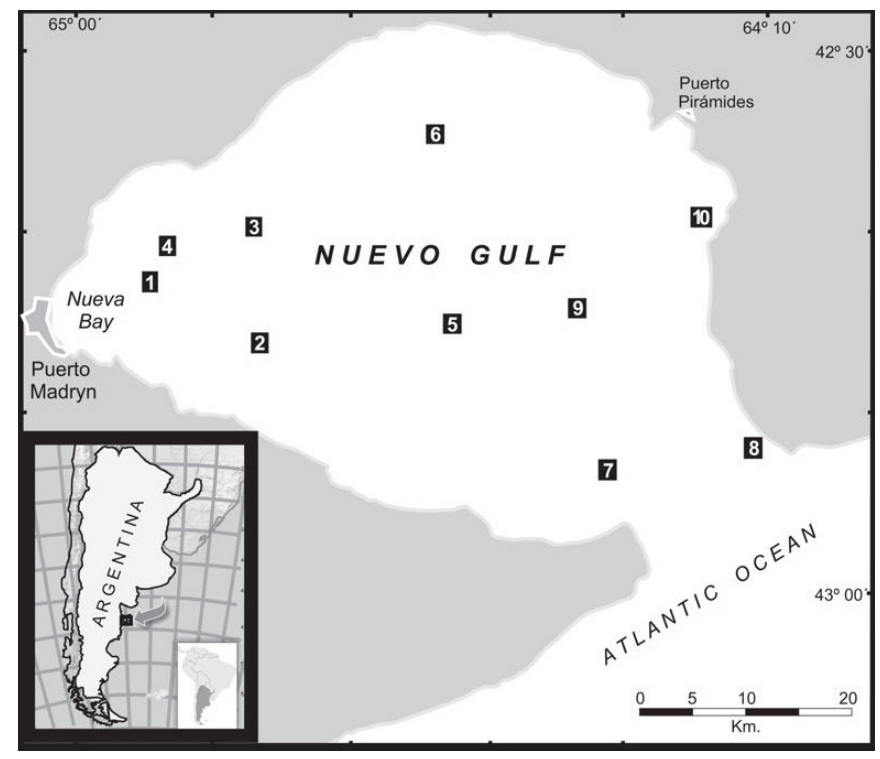

FIGURE 1. Map of the study area showing the location of sampling stations. 

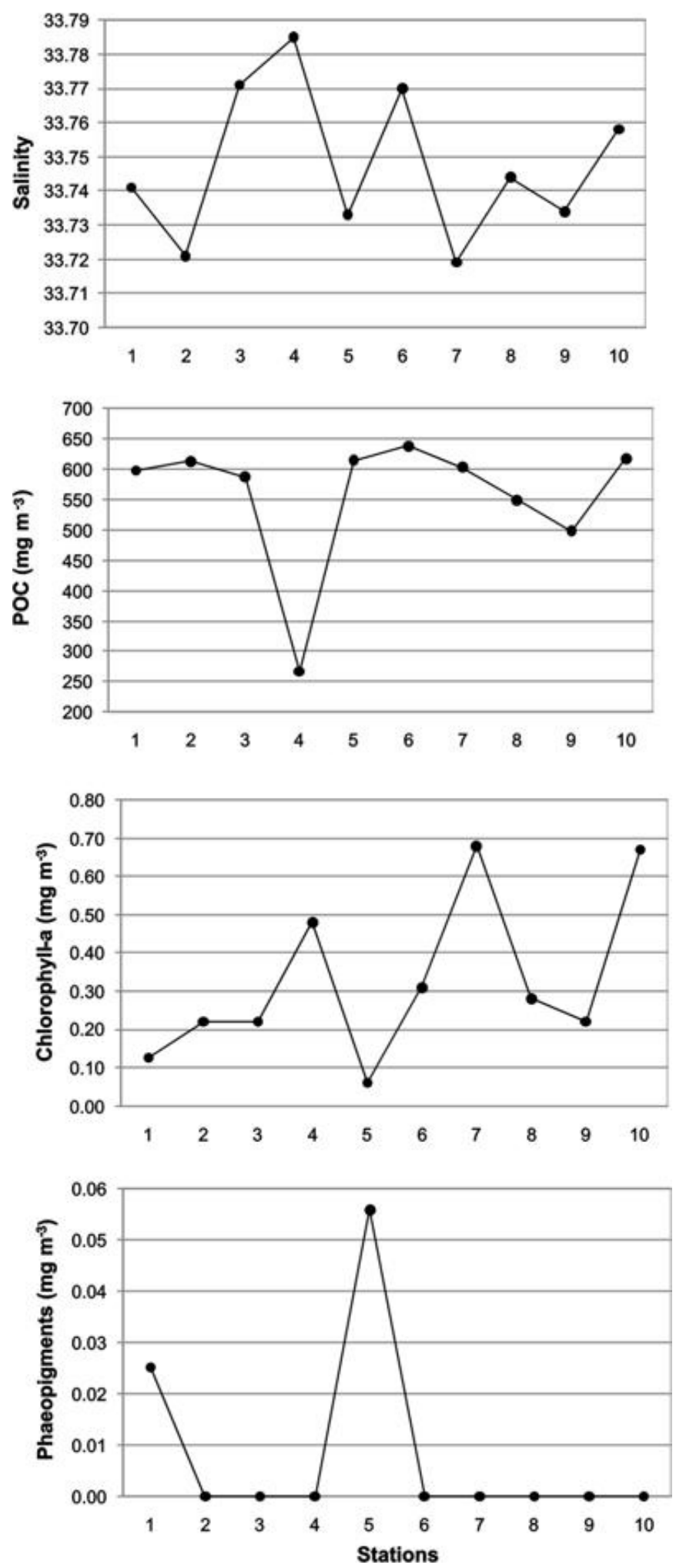

FIGURE 2. Surface salinity, POC, chlorophyll-a and phaeopigments distribution during the study period.

Total mesozooplankton abundance varied between 183 and 3529 ind. $100 \mathrm{~m}^{-3}$ (Figure 3). Stations 1 and 4 showed maximum values whereas station 9 showed the lowest values (Figure 3). Holoplankton dominated numerically on meroplankton at all stations, finding its highest total abundances at stations 1 and 4 and the lowest at station 9 (Figure 4). The highest meroplankton abundance was found at station 4 (140.15 ind. $100 \mathrm{~m}^{-3}$ ) (Figure 4). The copepod $C$. vanus was by far the most abundant taxa (59.8\% of the total holoplankton abundance) followed by
TABLE 1. Surface mesozooplankton taxa found in Nuevo Gulf. Mean: mean abundance. R: range. RA\%: relative abundance. $0 \%$ : percentage of occurrence in the samples. L: larvae. E: eggs. * Only one data.

\begin{tabular}{|c|c|c|c|c|}
\hline \multirow{2}{*}{ TAXA } & \multicolumn{3}{|c|}{ ABUNDANCE (IND $100 \mathrm{M}^{-3}$ ) } & \multirow{2}{*}{$\begin{array}{c}\text { OCURRENCE } \\
\mathbf{0} \%\end{array}$} \\
\hline & MEAN & $\mathbf{R}$ & $\mathbf{R A} \%$ & \\
\hline Paracalanus parvus & 455.74 & $39.47-927.35$ & 26.607 & 100 \\
\hline Ctenocalanus vanus & 1001.66 & $86.01-2252.35$ & 58.478 & 100 \\
\hline Calanus australis & 48.85 & $5.89-114.88$ & 2.852 & 100 \\
\hline Calanoides carinatus & 1.10 & $1.09-2.63$ & 0.064 & 70 \\
\hline Labidocera fluviatilis & 0.23 & $0.58-1.17$ & 0.014 & 30 \\
\hline Pontella marplatensis & 0.80 & $0.58-2.35$ & 0.047 & 50 \\
\hline Acartia tonsa & 6.61 & $1.17-20.51$ & 0.386 & 90 \\
\hline Oithona similis & 54.84 & 21.6-106.05 & 3.202 & 100 \\
\hline Oithona nana & 23.10 & $1.76-47.34$ & 1.349 & 100 \\
\hline Euterpina acutifrons & 15.61 & $1.76-31.56$ & 0.911 & 100 \\
\hline Monstrilla helgolandica & 0.12 & $1.17^{*}$ & 0.007 & 10 \\
\hline Monstrilla grandis & 0.14 & $0.58-0.77$ & 0.008 & 20 \\
\hline Podon intermedius & 32.12 & $1.76-126.25$ & 1.875 & 90 \\
\hline Evadne nordmanni & 3.17 & $0.52-11.19$ & 0.185 & 70 \\
\hline Bosmina sp. & 0.48 & $1.3-3.53$ & 0.028 & 10 \\
\hline Misydopsis rionegrensis & 0.13 & $1.3^{*}$ & 0.008 & 10 \\
\hline Themisto gaudichaudii & 0.05 & $0.52^{*}$ & 0.003 & 10 \\
\hline Euphausia lucens & 6.02 & $0.58-27.69$ & 0.352 & 60 \\
\hline Oikopleura dioica & 23.57 & $3.92-64.21$ & 1.376 & 100 \\
\hline Tisbe varians & 0.12 & $1.17^{*}$ & 0.007 & 10 \\
\hline Obelia sp. & 0.18 & $1.76^{*}$ & 0.010 & 10 \\
\hline Decapoda (L) & 0.23 & $0.58-1.17$ & 0.014 & 30 \\
\hline Cirripedia (L) & 0.30 & $0.58-1.3$ & 0.017 & 30 \\
\hline Gastropoda (L) & 26.62 & $7.07-96.03$ & 1.554 & 100 \\
\hline Briozoa (L) & 4.04 & $0.58-9.42$ & 0.236 & 100 \\
\hline Ciona intestinalis & 3.35 & $0.58-20.62$ & 0.196 & 70 \\
\hline Ascidiacea (L) & 1.26 & $0.58-5.89$ & 0.074 & 50 \\
\hline Ophiuroidea (L) & 0.06 & $0.58 *$ & 0.003 & 10 \\
\hline Polynoidae (L) & 0.55 & $0.52-1.55$ & 0.032 & 50 \\
\hline Spionidae I (L) & 0.23 & $0.58-1.76$ & 0.014 & 20 \\
\hline Spionidae II (L) & 0.79 & $0.58-1.76$ & 0.046 & 70 \\
\hline Teleostei (E) & 0.79 & $0.58-1.76$ & 0.046 & 70 \\
\hline
\end{tabular}

P. parvus (27.2\%), with mean abundances of 1001 and 455 ind. $100 \mathrm{~m}^{-3}$, respectively. Due to their great dominance, the distribution pattern of these copepods practically reflects the total mesozooplankton distribution. Other common taxa, though with lower abundances, were $O$. similis (3.2\%), C. australis (2.9\%), O. nana (1.3\%) and $P$. intermedius (1.9\%). Gastropoda veligers dominated the meroplanktonic fraction (69.31\% of the total meroplankton abundance), with a mean abundance of 26 ind. $100 \mathrm{~m}^{-3}$. The remaining taxa showed mean abundances lower than 5 ind. $100 \mathrm{~m}^{-3}$.

The taxa recorded in the present study are, in general, indicative of subantartic and estuarine coastal waters (Ramirez 1996; Sabatini and Martos 2002). The holoplankton fraction showed a homogeneous distribution evidenced through a high number of taxa with high occurrence as well as a similar composition among stations. In contrast, meroplankton showed a more heterogeneous distributional pattern which was mainly related to the proximity of each station to benthic populations in the coastal areas. Pelagic copepods were 
the most abundant group in Nuevo Gulf. Studies on other gulfs yield similar results on the dominance of copepods in mesozooplanktonic communities (Lavaniegos-Espejo and Lara 1990; Licandro et al. 2001; Durbin et al. 2003; D'Alcalà et al. 2004). As mentioned, data currently available on mesozooplankton of Nuevo Gulf is scarce and mainly focused only in the Nueva Bay area. C. vanus was the dominant taxon in this study, species that was previously reported by Esteves et al. (1996) as a common one in offshore waters of Nueva Bay during winter months. P. parvus was the other species registered as dominant in Nuevo Gulf and it has been considered as the most abundant taxon in Nueva Bay waters during winter (Esteves et al. 1996). Although P. parvus is considered the dominant taxon in the coastal waters of Nueva Bay, this study revealed that it would be gradually replaced by $C$. vanus through off-shore waters. The copepods O. nana, O. similis, and E. acutifrons were also reported in Nueva Bay by Esteves et al. (1996). In relation to $C$. australis, another taxon registered during this study, Sabatini et al. (2000) found that this species was the most abundant copepod along the coast of southern Patagonia and presented a distributional pattern in waters of the inner and middle shelf off of Argentina. Towards the north or at $46^{\circ} \mathrm{S}$, its distribution range partially overlaps with that of $C$. carinatus and this becomes evident in the area of Valdés Peninsula (Ramirez and Sabatini 2000; Sabatini et al. 2000). Esteves et al. (1996) recorded C. australis in Nueva Bay, with highest abundances in offshore waters. Interestingly, our observations indicate that this pattern is in agreement with the occurrence of $C$. australis in the rest of Nuevo Gulf, whose presence in this area could be due to the drift of southern continental shelf waters into the gulf.

Non-copepod holoplankton such as cladocerans and appendicularians is also very common in Nueva Bay waters (Esteves et al. 1996). In addition, the cladoceran $P$. intermedius and E. nordmanni were observed in this bay during winter (Esteves et al. 1996). On the other hand, it is well known that the appendicularian $O$. dioica is a coastal species widely distributed over the Argentine Sea (Esnal 1981) and it occurs at high concentrations in northern Patagonia (Sabatini and Martos 2002). Besides, both cladoceran species and 0 . dioica were found in high concentrations in the tidal frontal system of Valdés Peninsula (Sabatini and Martos 2002). In relation to meroplankton, the Gastropoda larvae, dominant group in our research, were also found in Nueva Bay waters by Esteves et al. (1996) and in San Matías Gulf by Ramirez (1996).

\section{Multivariate analysis}

Figure 5 shows the two-dimensional MDS ordination of the ten stations in Nuevo Gulf. The stress value obtained (0.02), corresponds to a good ordination with low risk of a misleading interpretation (Clarke and Warwick 1994). MDS plot revealed the existence of three groups of stations. Stations 1, 4, 7, 2 and 5 (southern and southwestern coast of the gulf) formed G1; stations 8, 3, 6 and 10 (northern and north-eastern coast of the gulf) formed G2; and station 9 (central area of the gulf) formed G3. These groups were mainly delimited by differences in zooplankton abundance and taxa richness. G1 was

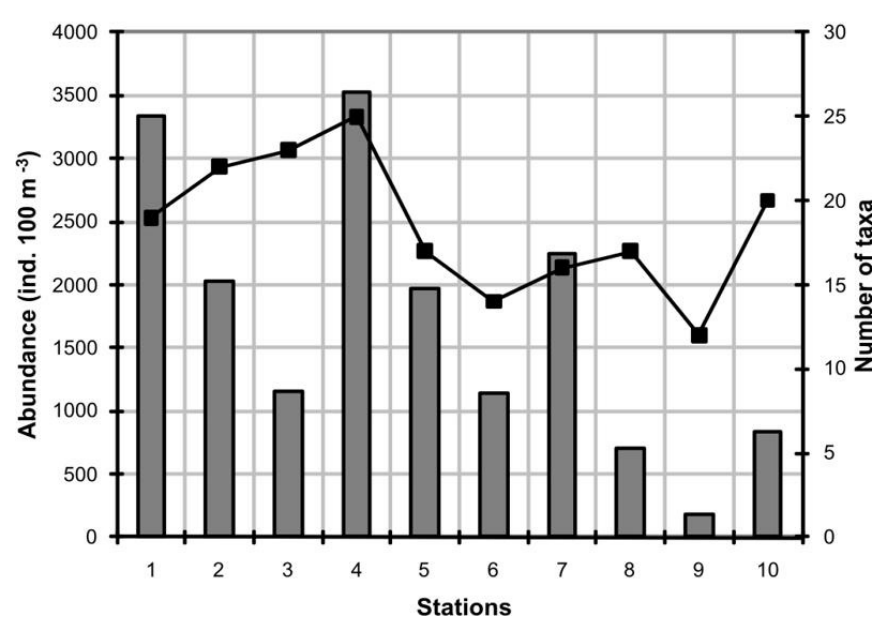

FIGURE 3. Total surface mesozooplankton abundances (bars) and number of taxa (line) at each station of Nuevo Gulf.

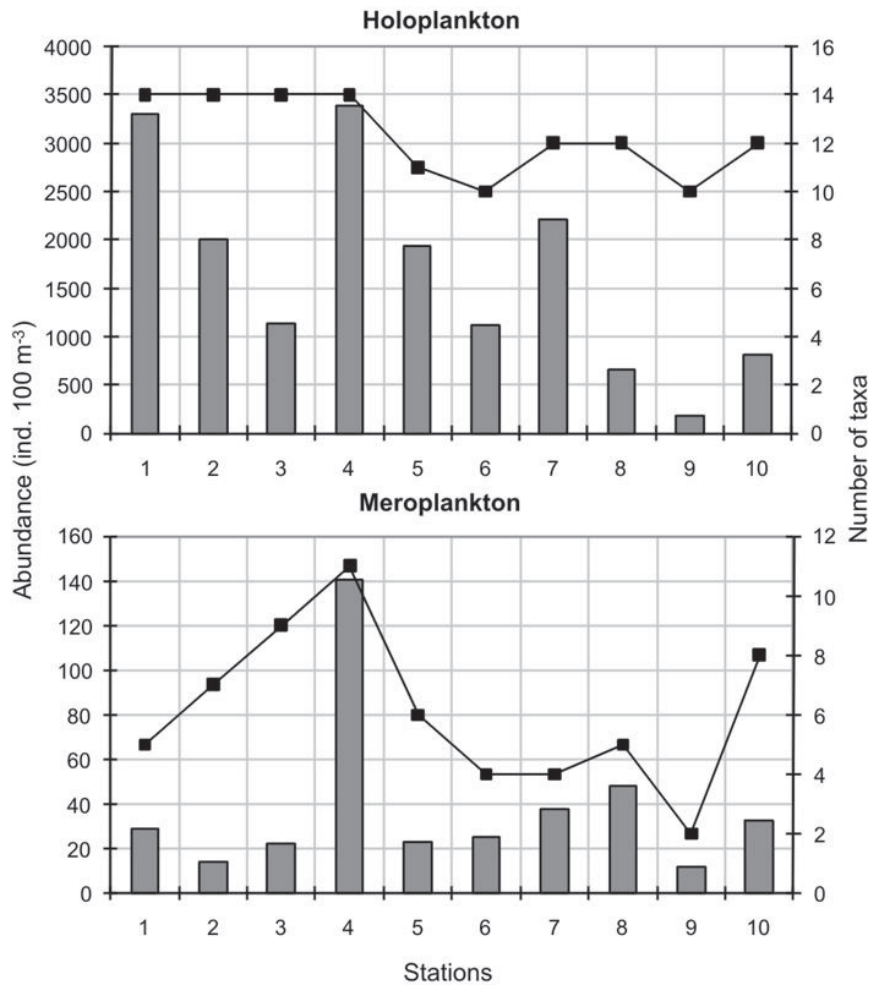

FIGURE 4. Surface holoplankton and meroplankton abundances (bars) and number of taxa (line) at each sampling station.

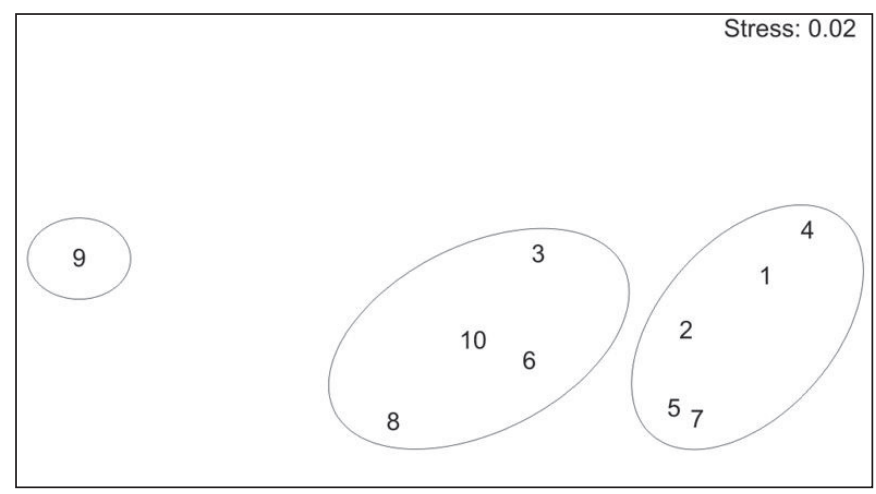

FIGURE 5. MDS plot showing the station groups observed in Nuevo Gulf.

characterized by high zooplankton abundances and taxa richness (Table 2). G2 showed intermediate abundances and taxa richness and G3 presented low values of both parameters (Table 2). The copepods C. vanus, $P$. parvus and $O$. similis were the indicators in all groups of 
stations (Table 2). The large copepod $C$. australis and the cladoceran $P$. intermedius also characterized G1 and G2 and Gastropoda larvae characterized G2 and G3 (Table 2 ). It is worth to mention that 0 . dioica was only relevant in G3 (Table 2). The arrangement of the stations relative to salinity, chlorophyll-a, phaeopigments and POC values showed a very homogeneous pattern since a single group was determined at the $85 \%$ similarity level. Thus, it was not possible to infer any relationship between the abiotic variables and the mesozooplankton distribution pattern. This could probably be not only for the absence of a clear gradient of such variables but also because of the temporarily punctual sampling design carried out in this survey.

Cluster analysis revealed the presence of six mesozooplanktonic assemblages (A, B, C, D, E and F) at approximately $30 \%$ similarity level (Figure 6). Assemblage

TABLE 2. Mean abundance (ind. $100 \mathrm{~m}^{-3}$ ) of each taxon in the different assemblages (A, B, C, D and F) and at each station group (G1, G2 and G3) present in Nuevo Gulf. In bold: highest mean abundances.

\begin{tabular}{|c|c|c|c|c|c|}
\hline & & & \multicolumn{3}{|c|}{ STATIONS GROUPS } \\
\hline & & & G1 & G2 & G3 \\
\hline & & & \multicolumn{3}{|c|}{ MEAN ABUNDANCE } \\
\hline \multirow{32}{*}{ 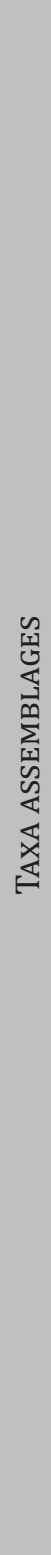 } & \multirow{2}{*}{ A } & Paracalanus parvus & 675.09 & 285.62 & 39.47 \\
\hline & & Ctenocalanus vanus & 1575.16 & 513.68 & 86.01 \\
\hline & \multirow{18}{*}{ B } & Calanus australis & 68.07 & 35.57 & 5.89 \\
\hline & & Calanoides carinatus & 1.30 & 1.12 & --- \\
\hline & & Pontella marplatensis & 1.01 & 0.59 & 0.58 \\
\hline & & Oithona similis & 81.94 & 28.20 & 25.92 \\
\hline & & Oithona nana & 38.34 & 9.40 & 1.76 \\
\hline & & Acartia tonsa & 9.71 & 4.11 & 1.17 \\
\hline & & Euterpina acutifrons & 20.12 & 13.43 & 1.76 \\
\hline & & Podon intermedius & 53.05 & 13.99 & --- \\
\hline & & Evadne nordmanni & 4.37 & 2.47 & --- \\
\hline & & Euphausia lucens & 9.90 & 2.53 & 0.58 \\
\hline & & Oikopleura dioica & 32.26 & 16.54 & 8.24 \\
\hline & & Gastropoda (L) & 34.52 & 21.05 & 9.42 \\
\hline & & Briozoa (L) & 3.38 & 5.29 & 2.35 \\
\hline & & Ciona intestinalis & 5.57 & 1.43 & --- \\
\hline & & Ascidiacea (L) & 2.07 & 0.57 & --- \\
\hline & & Polynoidae (L) & 0.88 & 0.27 & --- \\
\hline & & Spionidae II (L) & 0.58 & 1.24 & --- \\
\hline & & Teleostei (H) & 0.58 & 1.24 & --- \\
\hline & \multirow{2}{*}{$\mathrm{C}$} & Misydopsis rionegrensis & $--\cdot$ & 0.33 & --- \\
\hline & & Cirripedia (L) & --- & 0.74 & --- \\
\hline & \multirow{4}{*}{$\mathrm{D}$} & Tisbe varians & 0.23 & --- & --- \\
\hline & & Monstrilla helgolandica & 0.23 & --- & --- \\
\hline & & Bosmina sp. & 0.71 & 0.33 & --- \\
\hline & & Decapoda (L) & 0.35 & 0.15 & --- \\
\hline & \multirow{5}{*}{$\mathrm{E}$} & Labidocera fluviatilis & 0.35 & 0.15 & --- \\
\hline & & Monstrilla grandis & 0.27 & -- & -- \\
\hline & & Obelia sp. & 0.35 & --- & --- \\
\hline & & Ophiuroidea (L) & 0.12 & --- & --- \\
\hline & & Spionidae I (L) & 0.35 & 0.15 & --- \\
\hline & $\mathrm{F}$ & Themisto gaudichaudii & 0.10 & --- & --- \\
\hline
\end{tabular}

A represented the most abundant taxa which occurred at all stations (the copepods P. parvus and C. vanus). Assemblage $B$ included low abundance taxa mainly occurred at all stations, but also asciadians larvae were present with a low percentage of occurrence (Table 1 and 2). Assemblages C, $\mathrm{D}, \mathrm{E}$ and $\mathrm{F}$ included taxa with very low abundances (Table 2). C presented only two taxa (Mysidopsis rionegrensis Hoffmeyer, 1993 and Cirripedia larvae) with higher abundances at station 8 whereas D presented four taxa (T. varians, Monstrilla helgolandica Claus, 1863, Bosmina sp. Baird, 1850 and Decapoda larvae) occurring mainly at station 2. Assemblage E included five taxa (Obelia sp. Peron and Lesueur, 1810, Labidocera fluviatilis Dahl, 1894, Monstrilla grandis Giesbrecht, 1891, Spionidae I and Ophiuroidea larvae) with highest abundances at station 4 and $\mathrm{F}$ presented only one species (Themisto gaudichaudii Guerin Méneville, 1828), which was found only at station 7. The mesozooplanktonic assemblages from the dendrograms were subsequently superimposed on the MDS plot (Figure 6).

The groups of stations resulting from MDS analysis may reflect different environmental conditions in Nuevo Gulf during July 1997. G1 registered the highest abundances, stations 1 and 4 being those with maximum values. This is in agreement with the findings by Esteves et al. (1996) who observed that in studies carried out in Nueva Bay

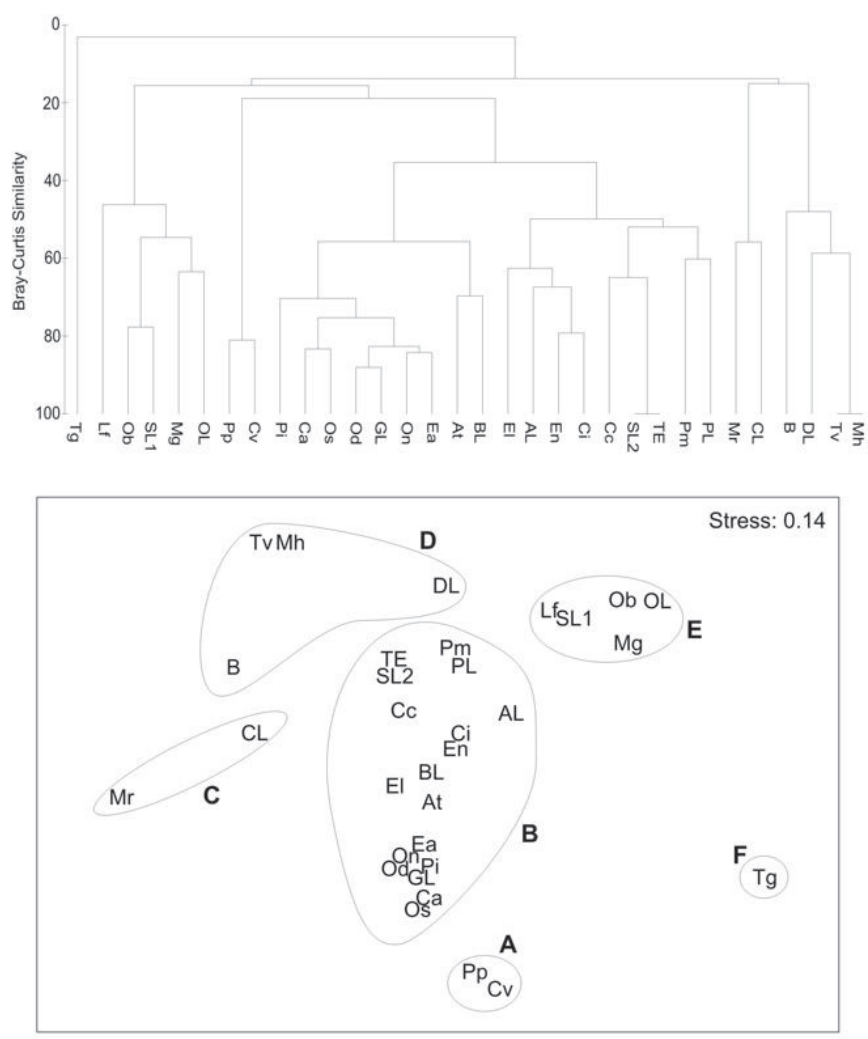

FIGURE 6. Cluster (A) and MDS plot (B) showing the mesozooplakton assemblages in Nuevo Gulf. Pp: Paracalanus parvus. Cv: Ctenocalanus vanus. Ca: Calanus australis. Cc: Calanoides carinatus. Lf: Labidocera fluviatilis. Pm: Pontella marplatensis. At: Acartia tonsa. Os: Oithona similis. On: Oithona nana. Ea: Euterpina acutifrons. Mh: Monstrilla helgolandica. Mg: Monstrilla grandis. Pi: Podon intermedius. En: Evadne nordmanni. B: Bosmina sp. Mr: Mysidopsis rionegrensis. Tg: Themisto gaudichaudii. El: Euphausia lucens. Od: Oikopleura dioica. Tv: Tisbe varians. Ob: Obelia sp. DL: Decapoda Larvae. CL: Cirripedia Larvae. GL: Gastropoda Larvae. BL: Briozoa Larvae. Ci: Ciona intestinalis. AL: Ascidiacea Larvae. OL: Ophiuroidea Larvae. PL: Polynoidae Larvae. SL1: Spionidae Larvae I. SL2: Spionidae Larvae II. TE: Teleostei Eggs. 
during 1993-1995, the highest abundances of zooplankton were recorded at the sampling points close to the coast and to others which geographically coincide with our stations 1 and 4 . These authors found that nutrients, POC, and phytoplankton densities were higher at these stations. They reported that the nutrient input by anthropic contribution from the bay coast may give rise to an increase in the primary productivity and as a consequence, to an increase in zooplanktonic abundance. They also observed that the highest zooplankton abundances in these stations could be due, among other possible reasons, to the water circulation pattern in ciclonic sense registered in Nueva Bay. However, there is still no general consensus on the water circulation pattern inside the gulf. Results regarding the circulation of water masses in the western area have been reported by Krepper and Rivas (1979) and Rivas (1983), who agree that current velocities are low and that flow is influenced by topography. Krepper and Rivas (1979) concluded that there is no clear circulation pattern, which seems to depend on winds. On the other hand, Rivas (1983) did not find a good correlation between winds and currents. Tonini et al. (2006) applied a numeric barotropic tri-dimensional model forced by winds and tides in Nuevo Gulf. Based on several days of simulation with western winds (a typical phenomenon in this region), they found that the response of waters consisted in the formation of two recirculation gyres, a counterclockwise gyre in the south and another clockwise in the north. They also observed that the northern gyre seems to be stronger than the southern one. The distinct current velocities of both gyres may therefore produce differences in zooplankton abundance inside the gulf. In spite of the model restrictions and limitations of our data (scarce sampling stations inside the gulf and scarce number of measurements), the findings from our study lead us to interpret the highest abundances observed in Nuevo Gulf as retention mechanism resulting from the lower velocity currents of the southern gyre.

G2 showed intermediate zooplanktonic abundances with respect to those in G1 and G3. Remarkably, G2 coincided with the area of the highest permanence of the southern right whale inside the gulf during its breeding time (Hoffmeyer et al. 2010). The probable zooplankton consumption by these cetaceans seems to be one of the reasons that give support to the abundances registered. Such behaviour appears to correspond to an opportunistic foraging behaviour which has been reported for southern and northern right whales during their seasonal migration in winter and springtime (Mayo and Marx 1990, Best and Shell 1996, Kenney et al. 1995, Hoffmeyer et al. 2010). Although an unpublished technical report have mentioned the existence of low planktonic food abundance for whales on Valdés Peninsula in winter and spring, Payne (1995) and others studies later reported that right whales forage sporadically on this nursery ground. In addition, Hoffmeyer et al. (2010) reported the presence of many juvenile and adults of E. australis skim-feeding at the surface in the northern zone of Nuevo Gulf in 2005 (in a zone closely to our station 10). The feeding behaviour observed in southern right whales at Valdés Peninsula would allow these cetaceans to stay long enough on the nursery ground in order to enhance the development of their calves as well as to improve their physical condition at the end of spring (Hoffmeyer et al. 2010).

G3 differs from the other groups mainly because it presented the lowest abundance values and taxa richness. Holoplankton organisms showed very low abudances whereas meroplankton fraction was poorly represented. This may be explained by the geographical location of the station 9 (central area of the gulf, far from coastal zones) as well as to its high depth. The coastal zone of Nuevo Gulf seemed to be much more productive than the central basin area $(\sim 180 \mathrm{~m})$, indicating that water depth is an important factor influencing zooplankton distribution. On the other hand, meroplankton is usually more abundant in coastal areas because these sites are just the places where populations of adults are located. More detailed studies would be extremely useful in terms of understanding the dynamics of the ecosystem and the interrelationships between organisms and environment. As stated above, the present study focuses on the composition, abundance, and spatial distribution of surface mesozooplankton community in Nuevo Gulf during winter time. Though limited to only one date, results from our study are highly relevant particularly in view of the scarce current literature regarding this zone. Our results show that the spatial distribution of surface mesozooplankton in Nuevo Gulf seems to be basically influenced by the dominant hydrological circulation pattern of the region. On the other hand, the probable consumption by southern right whale, the depth of each station, the distance to the coasts, and the variability of abiotic conditions were additional factors that may explain the distributional pattern of mesozooplankton in Nuevo Gulf. Further studies taking into account the other seasons as well as current measurements will greatly contribute to a better understanding of the mesozooplankton community dynamics in this important study area.

ACKnowledgments: Authors are grateful to Lic. Ricardo Marques, Lic. Horacio Ocariz and Dr. Mónica Gil of the Centro Nacional Patagónico (CENPAT-CONICET), for their invaluable assistance during the campaign and laboratory tasks. We also thank Biol. M. Sofía Dutto and Luciano C. Salotto for the revision of the manuscript.

\section{Literature Cited}

Barros, V. and C.M. Krepper. 1977. Modelo estacionario del Golfo Nuevo. Acta Oceanographica Argentina 1: 11-29.

Best, P.B. and D.M. Schell. 1996. Stable isotopes in southern right whale (Eubalaena australis) baleen as indicators of seasonal movements, feeding and growth. Marine Biology 124: 483- 494.

Clarke, K.R. and R.M. Warwick. 1994. Changes in marine communities: an approach to statistical analysis and interpretation. UK: Natural Environment Research Council, Plymouth Marine Laboratory. 144 p.

D’Alcalà, M.R., F. Conversano, F. Corato, P. Lisandro, O. Mangoni, D. Marino, M.G. Mazzocchi, M. Modigh, M. Montresor, M. Nardella, V. Saggiomo, D. Sarno and A. Zingone. 2004. A. Seasonal patterns in plankton communities in a pluriannual time series at a costal Mediterranean site (Gulf of Naples): an attempt to discern recurrences and trends. Scientia Marina 68: 65-83.

Durbin, E.G., R.G. Campbell, M.C. Casas, M.D. Ohman, B. Niehoff, J. Runge and W. Wagner. 2003. Interannual variation in phytoplankton blooms and zooplankton productivity and abundance in the Gulf of Maine during winter. Marine Ecology Progress Series 254: 81-100.

Esnal, G. 1981. Appendicularia; pp. 809-828. In D. Boltovskoy (ed). Atlas del zooplancton del Atlántico Sudoccidental y métodos de trabajo con el zooplancton marino. Mar del Plata: Publicación Especial INIDEP.

Esteves, J.L., M. Solís, M. Gil, N. Santinelli, V. Sastre, C. Gonzalez-Raies, M. Hoffmeyer and M. Commendatore. 1996. Dos Bahías Patagónicas: Bahía Nueva-Bahía Engaño; pp. 64-70. In J.E. Marcovecchio (ed). Pollution processes in coastal environments. Mar del Plata: Universidad Nacional de Mar del Plata. 
Hoffmeyer, M.S., M.S. Lindner, A. Carribero, K. Fulco, M.C. Menéndez, M.D. Fernández Severini, S.L. Diodato, A.A. Berasategui, F. Biancalana and E. Berrier. 2010. Planktonic food and foraging of Eubalaena australis (Desmoulins, 1822) on Península Valdés (Argentina) nursery ground. Revista de Biología Marina y Oceanografía 45(1): 131-139.

Kenney, R.D., H.E. Winn and M.C. Macaulay. 1995. Cetaceans in the Great South Channel, 1979- 1989: right whale (Eubalaena glacialis). Continental Shelf Research 15: 385-414.

Krepper, R.C. and A. Rivas. 1979. Dinámica de las aguas costeras en Golfo Nuevo. Parte I: Medición con superficies derivantes. Acta Oceanographica Argentina 2: 83-104.

Kruskal, J.B. and M. Wish. 1978. Multidimensional scaling. Beverly Hills: CA Sage Publications. $487 \mathrm{p}$.

Lavaniegos-Espejo, B.E. and J.R. Lara-Lara. 1990. Zooplankton of the Gulf of California after the 1982-1983 El Niño Event: Biomass distribution and abundance. Pacific Science 44: 297-310.

Licandro, P., A. Conversi, F. Ibanez and J. Jossi. 2001. Time series analysis of interrupted long-term data set (1961-1991) of zooplankton abundance in Gulf of Maine (northern Atlantic, USA). Oceanologica Acta 24: 453-466.

Mayo, C.A. and M.K. Mark. 1990. Surface foraging behaviour of North Atlantic right whale and associated plankton characteristics. Canadian Journal of Zoology 68: 2214-2220.

Mazio, C.A., W.C. Dragani, F.J. Caviglia and J.L. Pousa. 2004. Tidal hydrodynamics in Golfo Nuevo, Argentina, and the adjacent continental shelf. Journal of Coastal Research 20: 1000-1011.

Payne, R. 1986. Long term behavioral studies of the Southern Right Wale (Eubalaena australis); pp. 161-167. In R.L. Brownell, P.B. Best and J.H. Prescott (ed). Right whales: past and present status. Cambridge: Report International Whaling Commission (Special Issue 10).

Ramírez, F.C. 1996. Composición, abundancia y variación estacional del zooplancton de red del golfo San Matías. Frente Marítimo 16 (Secc. A): $157-167$.
Ramírez, F.C. and M.E. Sabatini. 2000. The occurrence of Calanidae species in waters off Argentina. Hydrobiologia 439: 21-42.

Rivas, A.L. 1983. Análisis de la circulación costera en Golfo Nuevo. Acta Oceanographica Argentina 3: 49-66.

Rivas, A.L. 1989. Corrientes originadas por la acción del viento y la marea en el Golfo Nuevo. Geoacta 16: 185-205.

Rivas, A.L. and E.J. Beier. 1990. Temperature and salinity fields in the northpatagonic gulfs. Oceanologica Acta 13: 15-20.

Rivas, A.L. and P. Ripa. 1989. Variación estacional de la estructura termohalina de Golfo Nuevo, Argentina. Geofísica Internacional 28: 3-24.

Sabatini, M.E., F.C. Ramírez and F.C. Martos. 2000. Distribution pattern and population structure of Calanus australis Brodsky, 1959 over the southern Patagonian Shelf off Argentina in summer. ICES Journal of Marine Science 57: 1856-1866.

Sabatini, M. and P. Martos. 2002. Mesozooplankton features in a frontal area off northern Patagonia (Argentina) during spring 1995 and 1998. Scientia Marina 66: 215-232.

Strickland, J.D.H. and T.R. Parsons. 1972. A practical handbook of seawater Analysis. Canadá: Bulletin of Fishery Research Board. 310 p.

Tonini, M., E. Palma and A. Rivas. 2006. Modelo de alta resolución de los Golfos Patagónicos. Mecánica Computacional 23: 1441-1460.

RECEIVED: Ocotber 2010

LAST REVISED: December 2010

ACCEPTED: December 2010

Published ONLINE: March 2011

EDITORIAL RESPONSIBILITY: Luis Ernesto Arruda Bezerra 